ВИЗНАЧЕННЯ ПОНЯТТЯ ПРОФЕСІЙНОЇ КОМПЕТЕНТНОСТІ МАЙБУТНЬОГО ВИКЛАДАЧА МУЗИКИ У ПРАЦЯХ КИТАЙСЬКИХ ТА УКРАЇНСЬКИХ НАУКОВЦІВ

\title{
DEFINING THE CONCEPT OF PROFESSIONAL COMPETENCE OF A FUTURE MUSIC TEACHER IN THE WORKS OF CHINESE AND UKRAINIAN SCHOLARS
}

у статmі зазначено, що в сучасному суспільстві значно підвищуються вимоги до просресійної підготовки викладачів музики для вищої школи, які не тільки здійснюють процес навчання студентів музичного профрілю, але й виконують провідну роль у формуванні їхньої духовної культури. Розкрито різні підходи китайських та українських учених до визначення поняття професійної компетентності майбутніх викладачів музики. Установлено, що в педагогічній літературі немає компаративних досліджень, у яких би проводився порівняльний аналіз трактувань зазначеної компетентності науковиями КНР та України Сорормульовано мету статі, котра полягає у зіставленні трактувань профресійної компетентності майбутніх викладачів музики у працяхкитайськихтаукраїнськихдослідників. Як визначено в дослідженні, під поняттям профресійної компетентності майбутнього викладача музики в українській науковій літературі зазвичай мається на увазі профресійно-особистісне утворення педагога, що $\epsilon$ результатом оволодіння ним комплексом музично-педагогічних знань, умінь, якостей і забезпечує його готовність до профресійно діяльності. Китайські вчені трактують це поняття як сорормованість у викладача музиканта необхінних педагогічних і музичних знань і вмінь, готовності до здійснення постійного просресійно-особистісного самовдосконалення, а також професійно важливих якостей.

Узагальнюючи отримані результати, у статті було зроблено висновок про те, що у процесі проведення компаративного дослідження проблеми формування професійної компетентності у викладачів-музикантів у вищій школі КНР та України під зазначеним поняттям розумітиметься інтегративна якість фрахівия, яка засвідчує його готовність до успішного викладання музичних дисциплін і проявляється в комплексі відповідних знань, умінь, ціннісних ставлень та особистісних якостей.

Ключові слова: просресійна компетент ність, викладач музики, Україна, Китай, компаративне дослідження.
It was point out in the article states that in modern society the requirements for vocational training of music teachers for high education establishment are increasing, that is not only carry out the process of teaching students of music profile, but also play a leading role in the formation of their spiritual culture. Different approaches of the Chinese and Ukrainian authors to defining the concept of professional competence of future music teachers have been revealed. It is established that in the pedagogical literature there are no comparative studies in which comparative analysis of interpretations of the indicated competence by the scientists of China and Ukraine would be carried out. The purpose of the article was formulated, that is to compare the interpretations of the professional competence of future music teachers in the works of Chinese and Ukrainian scholars.

As it was defined in the study, under the concept of the professional competence of a future music teacher in the Ukrainian scientific literature, as a rule, refers to the professional and personal education of the teacher, that is the result of mastering him a complex of musical and pedagogical knowledge, skills, qualities and ensure his readiness for professional activity. Chinese scientists interpret this concept as the formation of the teacher-musician of the necessary pedagogical and musical knowledge and skills, the willingness to exercise constant professional and personal self-improvement, as well as professionally important qualities.

Summarizing the obtained results, it was made in the article that the conclusion in the process of conducting a comparative study of the problem of the professional competence formation in music teachers in the high education high establishment of the People's Republic of China and Ukraine, the term will be understood as integrative quality of the specialist, that certifies his readiness for successful teaching manifested in the complex of relevant knowledge, skills, values and personal qualities.

Key words: professional competence, music teacher, Ukraine, China, comparative study. педагогічного університету імені Г.С. Сковороди

Постановка проблеми у загальному вигляді. У сучасному суспільстві значно підвищуються вимоги до профресійної підготовки викладачів музики для вищої школи, які не тільки здійснюють процес навчання студентів музичного профрілю, але й виконують провідну роль у формуванні музичної культури як важливої складової частини духовної культури особистості. Результатом зазначеної підготовки фрахівців має стати сформованість у них профресійної компетентності.

Слід відзначити, що проблема фрормування цієї компетентності у викладачів музики є важливим завданням для вищої школи різних країн, у т. ч. Китаю та України. Доробки з окресленої проблеми китайських педагогів можуть стати в нагоді для підвищення ефрективності процесу фрормування професійної компетентності викладачів-музикантів в українських закладах вищої освіти. У свою чергу, це передбачає узгодження у розумінні суті цієї компетентності дослідниками обох названих країн.

Аналіз основних положень і публікацій. Як установлено у процесі дослідження, китайськими й українськими вченими проаналізовано окремі питання, пов'язані 3 порушеною пробле- 
мою. Так, суть професійної компетентності педагога розкрито у працях Ву Юде, С. Гончаренка, О. Дубасенюк, Лі Йіхуй, Н. Ничкало, О. Савченко, В. Семиченко та ін. Основні вимоги до організації та здійснення музично-педагогічної освіти в КНР та Україні схарактеризовано такими вченими, як Гу Юй Мей, Г. Падалка, О. Ростовський, О. Рудницька, Чжан Цзянь Го, Ян Хун Нянь та ін. Авторські визначення поняття професійної компетентності майбутнього вчителя музичного мистецтва у школі й викладача музики у закладів вищої освіти містяться в публікаціях Т. Пляченко, І. Полубояриної, А. Растригіної та ін. Водночас аналіз наукової літератури із зазначеної проблеми дозволив установити відсутність компаративних досліджень, у яких би проводився порівняльний аналіз трактувань поняття професійної компетентності майбутнього викладача музики китайськими й українськими вченими. Наведені міркування свідчать про актуальність обраної теми статті.

Мета статті - зіставити визначення професійної компетентності майбутнього викладача музики у працях китайських та українських науковців.

Виклад основного матеріалу. Для кращого усвідомлення суті вказаного вище феномену доцільно було спочатку з'ясувати, як визначається в науковій літературі КНР та України поняття професійної компетентності викладача вищої школи. Так, нами визначено, що В. Саюк під цим поняттям розуміє інтегративну професійно-особистісну характеристику фахівця, яка включає гуманістичні ціннісні орієнтації, загальнопедагогічні, фрахові та функціональні знання, професійно важливі вміння й навички, особистісні якості, що в сукупності дозволяють забезпечити досягнення ефективного результату діяльності [7]. Схожі думки висловлює В. Стрельников, за яким професійна компетентність викладача вищої школи - це інтегральна характеристика, що $€$ результатом поєднання відповідних знань і вмінь, здатності до емоційновольової регуляції та проявляється в рівнях засвоєння передбачених компетенцій [8, с. 279].

Л. Отрощенко у своїй публікації використовує близький за значенням термін «професійно-педагогічна компетентність викладача ВНЗ», який трактує як інтегративну профресійно-особистісну характеристику педагога, що охоплює сукупність сформованих у нього професійно важливих знань (педагогічних, управлінських, етичних, психологічних тощо), умінь і навичок, творчого мислення, готовності йти на ризик і брати на себе відповідальність за власні дії, ціннісного ставлення до педагогічної діяльності, володіння інноваційними освітніми технологіями [4, с. 352].

У свою чергу, китайські фахівці у Чжихуа та Лю Хаймінь стверджують, що профеесійна компетентність викладача $€$ результатом оволодіння ним відповідних педагогічних умінь і здібностей, які забезпечують успішність практичної діяльності та $€$ основою для подальшого профресійноособистісного росту педагога [10]. Лі Йіхуй вважає, що вказана компетентність $€$ результатом оволодіння викладачем своєю професією під час навчання у вищій школі, причому ця компетентність продовжує підвищуватися під час здійснення педагогом самостійної професійної діяльності. На думку дослідника, зазначена компетентність проявляється в напруженій професійній діяльності, реалізації прагнення до власного професійного самовдосконалення й особистісної самореалізації [12].

Інший китайський вчений Ву Юде зазначає, що професійна компетентність викладача проявляється в оволодінні основними якостями та здібностями, необхідними для навчання та викладання. Як підкреслює автор, педагог не тільки повинен володіти професійно-музичними знаннями та вміннями, але й формувати їх у суб'єктів власного педагогічного впливу [14].

В електронній енциклопедії також стверджується, що професійна компетентність відображає готовність фахівця до здійснення професійної діяльності, ссрормованість його професійних здібностей, які дозволяють зробити висновок про рівень обізнаності фахівця у відповідній сфрері, а також відповідні вміння (інтелектуальні, соціальні, викладацькі., комунікативні тощо) [13].

Зазначимо, що особлива увага у процесі наукового пошуку приділялася аналізу наукових працях, у яких автори пропонували визначення саме поняття профресійної компетентності викладача музики. Так, Л. Гаврілова й О. Козіна стверджують, що професійна компетентність викладача музики $є$ специфрічним педагогічним френоменом, який визначається особливостями музично-педагогічної діяльності фрахівця, специфрікою її завдань, домінуванням художньо-творчих фоорм практичної роботи та специфрічними методами організації музичної освіти [1; 2].

М. Михаськова трактує вказане поняття як здатність педагога до музично-освітньої діяльності на основі опанування музично-педагогічних знань і вмінь, а також формування власного досвіду емоційно-ціннісного ставлення до явищ музичного мистецтва [3, с. 13]. Т. Пляченко сприймає профресійно-педагогічну компетентність викладача музики як системне поєднання його ціннісних настанов, професійно важливих знань і вмінь, а також володіння відповідними освітніми методиками [5, с. 13].

І. Полубоярина трактує професійну компетентність майбутнього вчителя музики як професійно-особистісне утворення, що $є$ результатом оволодіння фахівцем комплексом музично-педагогічних знань, умінь, якостей і забезпечує його готовність до профресійної діяльності [6, с. 8]. 
Н. Юдзіонок під вказаною компетентністю розуміє інтегративну професійно-особистісну якість, що визначає здатність педагога до осягнення художньо-змістової суті музичного твору та її матеріально-звукового втілення і $€$ підґрунтям для здійснення інших видів професійної діяльності, набуття досвіду прояву емоційно-ціннісного ставлення до музичних явищ [9, с. 8].

Аналізуючи погляди китайських учених на окреслене питання, Цай Ювей зазначає, що профресійна компетентність викладача музики передбачає не тільки засвоєння ним професійно важливих знань і вмінь, але й прояв яскраво вираженого позитивного емоційно-ціннісного ставлення до музики, ентузіазму, креативності, бо тільки так педагог може виховати любов до музики у студентів. А це, на думку автора, $є$ не менш важливою справою, ніж розвиток у студентів виконавської техніки [14].

Сюй Кунчао вважає, що професійна компетентність викладача музики проявляється у сформованості в нього педагогічних і музичних знань і вмінь, готовності до здійснення постійного професійно-особистісного самовдосконалення, а також таких професійно важливих якостей, як щирість і впевненість у собі, обережність, почуття гумору, ентузіазм, толерантність, розсудливість, комунікабельність, креативність [11].

Висновки. Отже, підводячи підсумки викладеним вище міркуванням китайських та українських учених, можна зазначити, що у розкритті ними суті професійної компетентності майбутніх викладачів музики суттєвих суперечностей немає. На підставі цього зроблено висновок про те, що у процесі проведення компаративного дослідження проблеми формування вказаної компетентності у викладачів-музикантів у вищій школі КНР та України під указаним поняттям розумітимемо інтегративну якість педагога, яка засвідчує його готовність до успішного викладання музичних дисциплін і проявляється в комплексі відповідних знань, умінь, ціннісних ставлень та особистісних якостей.

У найближчій перспективі планується проаналізувати теорію фрормування професійної компетентності майбутніх викладачів музики, викладену у працях китайських та українських науковців.

\section{БІБЛІОГРАФІЧНИЙ СПИСОК:}

1. Гаврілова Л.Г. Професійна компетентність майбутніх учителів музики як педагогічний феномен. Духовність особистості: методологія, теорія $i$ практика. 2017. № 2 (77). С. 71-82.

2. Козіна О. Формування профресійної компетентності майбутнього вчителя музичного мистецтва на заняттях хорового диригування. Проблеми підготовки сучасного вчителя. 2019. Вип. 1 (19). С. 64-71.

3. Михаськова М.А. Формування фрахової компетентності майбутнього вчителя музики : дис. ... канд. пед. наук : 13.00.02. Київ, 2007. 228 с.

4. Отрощенко Л.С. Профресійно-педагогічна компетентність викладача як умова ефективного дидактичного процесу у ВНЗ економічного профрілю. Педагогічні науки: теорія, історія, інноваційні технології. 2015. № 1 (45). С. 346-354.

5. Пляченко Т.М. Компетентнісна модель у структурі фрахової підготовки майбутнього вчителя музики. URL: http://elibrary.kubg.edu.ua/ 570/1/T_Plyachenko_ Kompetentnisna\%20model.pdf.

6. Полубоярина І. Формування профресійної компетентності майбутніх учителів музики в педагогічному коледжі : автореф. дис. ... канд. пед. наук : 13.00.04. Житомир, 2008. 21 с.

7. Саюк B.I. Профресійна компетентність як основа розвитку сучасного викладача в системі післядипломної педагогічної освіти. Нова педагогічна думка. 2012. № 3 (71). C. 57-61. URL: http://lib.iitta. gov.ua/7042/1/ Саюк_3_стаття.pdf.

8. Стрельников В. Компоненти профресійної компетентності викладача вищої школи. Гуманітарний вісник. 2013. № 28. С. 278-285.

9. Юдзіонок М.Н. Формування профресійної компетентності майбутнього вчителя у музично-інтерпретаційній діяльності : автореср. ... канд. пед. наук : 13.00.04. Одеса, 2011. 20 с.

10. 吴志华 柳海民. 论教师专业能力的养成及高师 教育课程的有效教学途径. 《教师教育研究》. 年03. 2004. URL: http://www.cnki.com.cn/Article/CJFD2004GDSZ200403005.htm.

11. 徐群超. 如何成為一位稱職的老師. URL: https://www.uensemble.org/writings-details.php?title=\& classsn $=8 \& s n=120$.

12. 李伊慧. 團體班音樂老師專業發展之敘事研究. 2010. URL: https://www.airitilibrary.com/Publication/ alDetailedMesh?docid=U0014-2102201023240700.

13. 职业能力. 全球专业中文经管百科. URL: https://baike.baidu.com/item/职业能力.

14. 蔡雨薇. 如何做一名优秀的音乐教师. URL: https://core.ac.uk/ download/pdf/41459845.pdf. 